\title{
Satan, Subliminals, and Suicide: The Formation and Development of an Antirock Discourse in the United States during the 1980s
}

On May 16, 1985, the American news program 20/20 featured a segment entitled "The Devil Worshippers." In his introduction to the segment, news anchor Hugh Downs explained that "[there] have been a series of criminal acts reported around the country that have had unique characteristics that [link] them together. And the source of all this is the apparent practice of Satanism. That's worship of the devil."1 Over the course of the next half hour, reporter Tom Jarriel, law enforcement officials, psychologists, and former cult members described a variety of "perverse, hideous acts that defy belief." In addition to reports of churches and graves being desecrated with satanic symbols (including inverted pentagrams and the number 666), "The Devil Worshippers" described how reports of murders, missing and abused children, and the slaughter of animals may be associated with satanic rituals and ceremonies.

In one of the most memorable scenes from "The Devil Worshippers," Jarriel enters a videocassette store to show how easy it is for young people to rent or buy films with occult themes, including The Exorcist, The Omen, Amityville Horror, and Rosemary's Baby. Next, Jarriel enters a bookstore, where he pulls copies of The Satanic Bible and The Satanic

John Brackett is a music instructor at Vance-Granville Community College. His research interests include avant-garde and experimental musical practices in the twentieth and twenty-first centuries, the role and place of music within "moral panics" in the United States during the twentieth century, and the history and analysis of various popular music artists, genres, and styles. He has published on the music of Frank Ocean, the Smiths, Led Zeppelin, Arnold Schoenberg, and John Zorn. With Ciro Scotto and Kenneth Smith, he is a coeditor of The Routledge Companion to Popular Music Analysis: Expanding Approaches (Routledge, forthcoming 2018). Using synthesizers and drum machines, he writes and records electronic dance music under the name Nary Goo-Man. 
Rituals from the shelves (both books written by Anton LaVey, the founder of the Church of Satan). Finally, Jarriel is shown in a record store, where, he claims, the "satanic message is clear, both in the album covers and in the lyrics, which are reaching impressionable young minds." As Jarriel's voice-over continues, Mötley Crüe's song "Shout at the Devil" plays in the background as viewers are shown album covers by heavy metal acts Ozzy Osbourne (Blizzard of Oz), Iron Maiden (The Number of the Beast), and Black Sabbath (Born Again). "And the musical message comes across loud and clear," Jarriel continues, "at concerts and now through rock videos. The symbolism is all there: the satanic pentagram, the upside-down cross, the blank eyes of the beast, the rebellion against Christianity, and again and again, the obsession with death."

Citing findings by police, Jarriel describes how heavy metal album covers, lyrics, videos, and live performances are influencing children and teenagers, including a "growing subculture that mixes heavy metal music with drugs and the occult." Furthermore, Jarriel continues, evidence gathered at murder scenes and suicides suggests links between heavy metal music and occult rituals. "How often do you find heavy metal music indicators at the scene of a crime involving devil worship?" Jarriel asks a police officer. "Probably about thirty-five, forty percent of the calls," the officer responds. Jarriel also describes how "in addition to groups that are blatantly satanic, there are also many recordings which some believe may contain satanic references in the form of backward messages." The scene cuts to show Jarriel sitting in a radio broadcasting booth with Chris Edmonds, a disk jockey. Edmonds plays a segment of Led Zeppelin's song "Stairway to Heaven" forward and, before playing the same segment of music backward, tells Jarriel that "a lot of people hear the phrase "my sweet Satan.'" After being told what to listen for when the section is played backward, Jarriel has no trouble hearing the hidden message: "my sweet Satan."

When the segment first aired in May 1985, the claims presented in "The Devil Worshippers" linking heavy metal music to Satanism were probably familiar to most American viewers. Since the early 1980s, a number of antirock preachers, politicians, and concerned parents had been engaged in a battle with many forms of contemporary rock and pop music, not just heavy metal. For these antirock activists, lyrical descriptions and visual depictions that glorified and promoted violence, sex, drug and alcohol abuse, and Satanism were symptomatic not only of the declining moral standards of many forms of popular entertainment (including television and film) but also of the overall moral decay of America. At the same time, many of these antirock activists argued that a great deal of contemporary music they deemed "objectionable" was dangerous through its ability to influence and modify the behavior and thoughts of vulnerable children and teenagers. 
As many scholars and critics have recognized, the antirock movement that emerged in America in the 1980s was a manifestation of the growing influence of (and connections between) religious fundamentalism and conservative political ideology. ${ }^{2}$ At the same time, many of the claims advanced by antirock activists were informed by a moral panic that swept across the nation beginning in the 1980s. Paralleling the growing influence of fundamentalist conservatism on American culture and politics during this time, the so-called Satanic Panic (or Satanism Scare) was fueled by an increasing number of news reports that suggested that an underground network of Satanists were active throughout all parts of American society. ${ }^{3}$

After briefly outlining some of the religious, political, and sociocultural conditions that helped the antirock movement flourish in the 1980s, I will discuss the background and content of one of the earliest reports linking popular music with Satanism: Assembly Bill 3741, a bill proposed before the California legislature in 1982. AB 3741 sought for the inclusion of warning labels on commercial recordings that purportedly contained backward messages that glorified Satanism and the occult. Drawing upon documents and testimony related to AB 3741, I will describe how supporters of the bill exploited contemporary fears regarding Satanism and behavioral modification by characterizing backward (or "backmasked") messages as a form of subliminal stimulation. Supporters of the bill argued that backward messages qua subliminal messages could be deciphered by the subconscious mind and, through repeated exposure, had the ability to modify the behavior and beliefs of unsuspecting listeners.

The arguments and claims presented in support of AB 3741 influenced much of the antirock discourse that dominated the 1980s. In addition to subliminal messages, many religious antirock authors argued that rock lyrics, album artwork, music videos, and live performances also posed an unmediated threat to impressionable listeners via their conscious minds. Many of these same writers suggested that the ability of various aspects of pop and rock music to modify the behavior and beliefs of children and teenagers often led to violent behavior and, in some instances, suicide. Beginning in 1985, the Parents' Music Resource Center (PMRC) employed many of the same dubious psychological claims regarding influence and behavior in their battle with the music industry regarding warning labels on recordings. The PMRC argued that socially irresponsible songs and videos-particularly those associated with heavy metal-were a contributing factor in many of the hardships and challenges facing America's youth, including teenage pregnancy, sexual exploitation, drug and alcohol abuse, and suicide. Finally, after years of speculation by politicians, religious antirock authors, and the PMRC, the ability of subliminal and backmasked messages to influence behavior was debated in courtrooms across the country as part of 
multiple wrongful death suits filed against heavy metal acts by parents of teenagers who had committed suicide.

\section{Sowing the Seeds of the "Satanism Scare" in America}

"The Devil Worshippers" introduced the topic of Satanism and occult activity in America to a national audience. At the same time, the segment provided a seemingly coherent explanation for a variety of antisocial behaviors and illegal activities that had previously been viewed as unrelated. Fueled by disturbing and often sensationalized accounts in the media as well as a variety of social, cultural, religious, and political factors, a moral panic concerning occult activities spread throughout the United States beginning in the early 1980s.

Many scholars have described conditions and factors that contributed to the rise of the "Satanism Scare," or the "Satanic Panic," that swept over America during this time. ${ }^{4}$ Beginning in the late 1970 s and continuing throughout much of the 1980s, American fundamentalist and evangelical Christians who believed in the existence of the devil, or Satan, as the source of all that is evil and corrupt in the world began to exert a strong influence on American culture and politics. In an effort to reverse the liberal tendencies that had shaped American politics since the 1960s and the "secular humanist" worldview that dominated American education and culture, many fundamentalists and evangelicals across the country formed political action committees (PACs) and lobbying groups in an effort to mobilize voters and support like-minded political candidates. Collectively referred to as the New Christian Right, organizations such as Christian Voice, the Roundtable, and Moral Majority, Inc., played a significant role in the 1980 national elections, most notably in the election of Ronald Reagan as president of the United States. ${ }^{5}$

The leaders and supporters of the New Christian Right were ideologically united around a core group of beliefs. ${ }^{6}$ As described by sociologist Jerome Himmelstein, the shared ideology of the New Christian Right included (1) the belief in the economic benefits and inevitable prosperity that would result from a market that is free of government interference and regulation; (2) the need for a shared set of traditional values to combat the perceived "moral decay" brought about by secular humanist teachings and liberal government policies; and (3) the need to rid the world of Communism. ${ }^{7}$ As Himmelstein notes, the "New Right identifies the same enemy within each area of concern; economic, social, and national security problems equally are blamed on liberals operating through the federal government." 8

Leaders of the New Christian Right often described their religiouspolitical aims as a battle between "good" (conservative fundamentalists and evangelicals) and "evil" (liberal secular humanists). In an effort to mobilize fundamentalists and evangelicals to participate in all levels 
of the American political process, Tim Lahaye, Jerry Falwell, and other leaders associated with the New Christian Right employed a rhetoric of fear that predicted the demise of America and ultimately the entire world if liberal, secular humanist beliefs and policies were not curtailed. ${ }^{9}$ In his contemporary critique, theologian Gabriel Fackre summarizes this rhetoric of fear whereby "secular humanists" and "liberals" are servants of "Satan [who are used] to promote homosexuality, abortion, divorce, adultery, pornography, the breakdown of the family life, the erosion of liberties, governmental tyranny, military weakness, the corruption of public education, and the spread of Marxism." ${ }^{10}$ For the New Christian Right and their followers, the Apocalypse is not inevitable. The battle between good (fundamentalists and evangelicals fighting under the banner of Jesus Christ) and evil (secular humanists doing the work of Satan) could be won through political activism.

For religiously devout people sympathetic to the political and cultural revolution led by the New Christian Right in the 1980s, the reports of satanic activity would have been understood as another example of how the "evil" influence of secular humanism was contributing to the moral decline of America. For another segment of the American population, however, "satanic" was understood as a metaphor that characterized the nontraditional beliefs, antisocial behaviors, and subversive acts associated with so-called cults. ${ }^{11}$ The rise of new religious groups during the 1960s and 1970s was still a concern for many Americans in the 1980s. Against the background of traditional Judeo-Christian values and beliefs, contemporary media accounts often emphasized the "bizarre" spiritual teachings of Anton LaVey's Church of Satan, the Unification Church (the "Moonies"), and the Hare Krishnas. Followers of new religious groups were often described in the media as "fanatics" who had been "brainwashed" by a charismatic leader who forced them to act against their will. The murders committed by followers of Charles Manson in California in 1969 and the mass suicides and murder of nearly a thousand members of Jim Jones's Peoples Temple in 1978 in Jonestown, Guyana, confirmed the suspicions and fears of many anticult activists. ${ }^{12}$ At the same time, allegations concerning the ritual abuse of children at daycare centers and preschools by "devil-worshipping" cults dominated news headlines in America during the 1980s. Between 1983 and 1987 journalist Debbie Nathan identified over one hundred cases involving the alleged ritual abuse of children in the United States. ${ }^{13}$ The numerous reports that vulnerable children were being exploited by alleged cult members united those people who believed that Satan is the "real" source of evil in the world as well as those who understood "Satanism" or "satanic" as metaphors for antisocial behavior. ${ }^{14}$

Many forms of popular entertainment were often identified as both a symptom and a cause of the moral decline of America. In 1981 Jerry Falwell and Reverend Donald Wildmon, founder of the Coalition for Better 
Television (CBTV), threatened to boycott the major television networks over charges of excessive and graphic depictions of sex, violence, drug use, and other forms of immoral behavior. ${ }^{15}$ For Wildmon, Falwell, and other like-minded religious leaders and organizations, network television executives and producers (routinely described as "liberals" or "humanists") were more interested in making money through advertising than programming "wholesome" programs acceptable for the entire family. ${ }^{16}$ Furthermore, Wildmon, Falwell, and their supporters argued that repeated exposure to morally objectionable behavior and images on network television had a direct, negative influence on America's youth.

In an attempt to protect the youth of America, supporters of the New Christian Right, concerned parents, and child advocacy groups turned their attention to the music industry. Writing in the Moral Majority Report (the official publication of Moral Majority, Inc., Jerry Falwell's political action committee), child advocate Glen C. Griffin described much contemporary pop and rock music as "audio pornography." 17 Citing lyrics from songs by Donna Summer ("Hot Stuff" and "Bad Girls"), Rod Stewart ("Do Ya Think I'm Sexy?"), and the Knack ("My Sharona"), Griffin warned that many songs are "wide open invites to, or descriptions of, experiences with drugs and sex." Turning his attention to the music, Griffin explained that "some of the pounding cacophony would seem to push every decent thought out of one's mind. Some of the sound vibrations in themselves are sensuously stimulating." Griffin suggested that repeated exposure to songs he considered examples of "audio pornography" can adversely affect children's behavior and beliefs. "Popular music," Griffin explained, "is tremendously effective advertising. If a 30-second commercial jingle sells millions of bottles of soft drink or tubes of toothpaste, imagine how well records pushing sex and drugs accomplish their objectives."18

Of course, Griffin's arguments regarding popular music's ability to negatively influence behavior through either "obscene" or "suggestive" lyrics or "sensuously stimulating" rhythms were not new; many of the same claims were made by critics of early rock and roll in the 1950s. ${ }^{19}$ At the dawn of the 1980s, however, these long-standing claims relating to the dangers of rock music resurfaced and were adapted by antirock activists who reflected the political and cultural climate of America.

\section{"My Sweet Satan": AB 3741, Backmasking, and Subliminal Suggestion}

In the spring of 1982 Monika Wilfley of Lancaster, California, contacted her local assemblyman, Phil Wyman (R-Tehachapi), to express her concerns regarding "secret messages" on rock albums. Wilfley recounted to Assemblyman Wyman how, earlier that year, she had viewed an episode 
of Praise the Lord (a television program broadcast on the Trinity Broadcast Network) that described the presence of hidden messages on many popular rock albums, messages that were decidedly anti-Christian and that glorified and celebrated Satan. Curious about the claims, Wilfley and her husband examined some of the recordings in their own collection by spinning records counterclockwise on a turntable. When the Wilfleys played the records backward, they were shocked to hear phrases such as "Here's to my sweet Satan" in Led Zeppelin's "Stairway to Heaven" and "Oh, Satan, move in our voices" in the song "Snowblind" by Styx. After confirming the presence of secret satanic messages on their favorite recordings, Wilfley and her husband destroyed many of their records and cassette tapes. "It was really frustrating," Wilfley explained, "[because] some of them were new."20

Assemblyman Wyman, a devout Christian, was appalled by Wilfley's claims. In his capacity as a member of the Committee on Consumer Protection and Toxic Materials, Wyman quickly drafted a bill that sought to regulate the inclusion of backward messages on phonographic recordings. Introduced on March 26, 1982, Wyman's bill-Assembly Bill 3741-defined backward masking (or simply backmasking) as a "process by which an audible verbal statement may be heard when the record is played backwards." Citing Wilfley and an unspecified "Christian Group," the bill summary explained that "proponents allege that the records of many rock groups contain anti-Christian and pro-Satanic messages transcribed on them by backward masking. They contend that while these messages are consciously understandable if the record is played backwards, these messages can also be perceived, unknowingly and subconsciously, by the listener when the record is played forward in the normal manner. Thus, listeners may be subjected to the 'hidden' influence of these messages without ever realizing it." AB 3741 would "require manufacturers of such records which contain 'backward masking' to place a specified warning statement on the record jacket." ${ }^{21} \mathrm{~A}$ warning label, Wyman believed, would alert listeners to the presence of spiritually and morally offensive messages on recordings and protect listeners from the ability of such messages to influence their behavior and beliefs.

A hearing on AB 3741 occurred on April 27, 1982. In his opening statement, Assemblyman Wyman downplayed the religious objections that spawned the bill by arguing that AB 3741 was a "consumer protection measure, and not just a religious measure." In support of his argument, Wyman played on the American public's long-standing fear that the media and advertisers can influence behavior through the use of subliminal messages. "By its very nature," Wyman explained, "subliminal advertising is accomplished without the conscious knowledge of the consumer. It attacks an unprotected and undefined portion of our brain. 
It constitutes a warrantless, unconsented, and outrageous invasion of the subconscious mind." ${ }^{22}$ By appealing to pop psychology, Wyman ignored a great deal of research that contradicted the supposed effectiveness of subliminal messages to influence behavior. ${ }^{23}$ At the same time, Wyman's argument posed a problem: How, exactly, were subliminal backward messages decoded by the subconscious mind?

The only witness to testify at the hearing on AB 3741 was William H. Yarroll II, president of Applied Potentials Institute, a management consulting firm based in Colorado. Citing his research at the University of Colorado Health Science Center, Yarroll claimed to be a neuroscientist specializing in the effects of subliminal messages. ${ }^{24}$ Yarroll provided testimony on how backward messages on rock-and-roll recordings are interpreted by the brain and provided a number of examples of songs that, in his opinion, contained backmasked satanic messages, including "Revolution 9" by the Beatles, "Snowblind" by Styx, and "Stairway to Heaven" by Led Zeppelin.

In a prepared document entitled "Rock Music: Does It Have a Secret Message?," Yarroll explained that backmasking originated with "The Beattles [sic], when during a brief time when their record sales were down . . . used the reverse side of their songs to intimate that Paul McCaurtney [sic] was dead." Whereas the Beatles supposedly employed backward messages to deceive the public into buying their records, contemporary rock artists, Yarroll claimed, had a more sinister reason for employing backmasked messages. "Unfortunately," Yarroll explained in his document, "today we have a common thread of backward masking on many of the popular rock albums with the same message. Blasphemy toward Jesus Christ, and calling on the listener to serve Satan as master, with distinct phrases of worship to Satan." 25 According to Yarroll, rock musicians and their record labels include hidden satanic messages on albums because "the Church of Satan and their followers have a pact, that if you perform certain things in your particular line of work, in return Satan will give you certain favors back."26

In his document, Yarroll explained how subliminal/backmasked messages are processed and interpreted by the brain and how these messages affect behavior and beliefs: "Psychiatrists are proving that the mind is so intricate that it will pick up all sounds on a tape or record, even if we do not hear them with the conscious mind. This means all these messages so deceptively placed on this rock music is [sic] getting within our subconscious mind without our awareness or choice! ... As we know, the subconscious constantly feeds messages and directions into our conscious mind, so once we realize what has been so deceptively thrust upon us, we need to guard our minds against such an unwanted invasion." 27 To illustrate his hypothesis, Yarroll provided a diagram related to his theory of the "Total System" of the human mind and the importance of the 
"Reticular Activating System" in interpreting and decoding stimuli (see figure 1). According to Yarroll's theory of the mind, all stimuli received by the "Body Receptors" (presumably, our senses) are first presented to the "Reticular Activating System," which compares the stimuli with known experiences, facts, or beliefs, stored in the "Memory Register," located in the brain's left hemisphere (the "Logic Hemisphere"). If no "truth" correspondence is found within the Memory Register / left brain, the stimuli are passed along to the right brain/hemisphere, the center of creativity and home to the unconscious. Once they are passed to the right hemisphere, the unrecognized stimuli (such as unknown, garbled phrases) enter the unconscious brain. Through repeated exposures, these stimuli are "decoded" and, over time, can become embedded in our long-term memory and can shift the balance of our attitudes and beliefs. These new, recently decoded stimuli are then fed back into the left hemisphere, where they become accepted, conscious "truths." The recently introduced stimuli-now accepted as "true" — have the ability to alter a person's "Self Image" and effect changes in attitudes, beliefs, interests, and behaviors. ${ }^{28}$

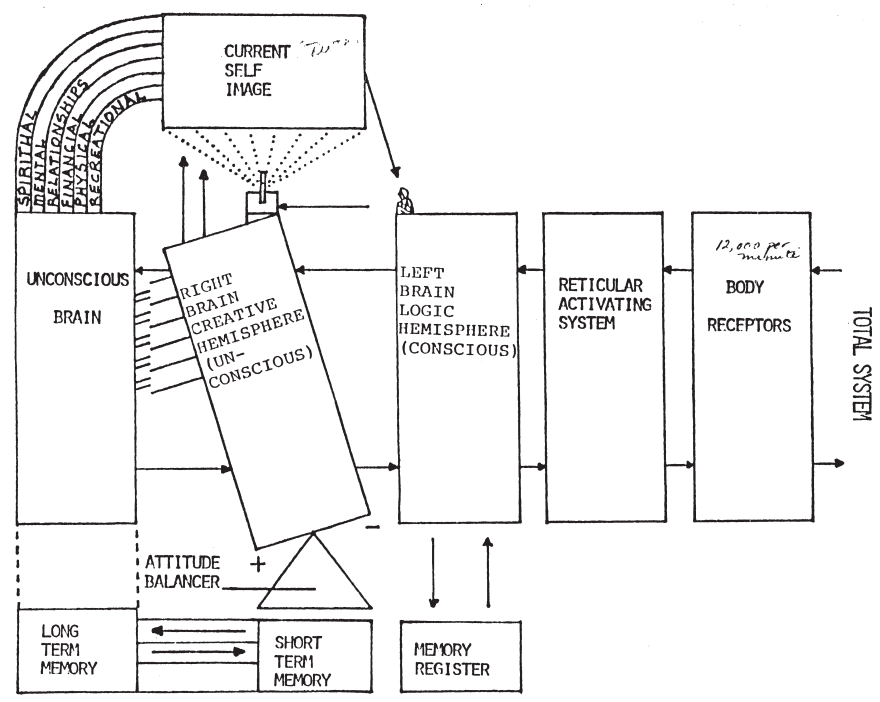

Figure 1. William H. Yarroll's theory of the "Total System" of the mind. Submitted in support of the Assembly Committee on Consumer Protection and Toxic Materials, AB 3741 (1982), California State Archives, Office of the Secretary of State, Sacramento. 
Despite Yarroll's testimony, the Committee on Consumer Protection and Toxic Materials returned a decision of "No Vote" on AB 3741, explaining that more research and supporting evidence on how subliminal messages affect behavior was needed. Pending the discovery of such supporting evidence, the bill could be reintroduced in the next legislative session.

Wyman's proposed legislation received a great deal of media coverage and elicited strong reactions from supporters and opponents. People opposed to AB 3741 often expressed disbelief and frustration that the California legislature would waste taxpayer money on what they considered a frivolous cause. Opponents also objected to the bill on constitutional grounds, citing freedom of speech and religion. In a letter submitted to the Los Angeles Times included in a communication with Sally Tanner, chairwoman of the Committee on Consumer Protection and Toxic Materials, Los Angeles resident Martin McCaffery expressed his opinion that the legislation proposed in AB 3741 "is not a consumer protection issue, it is a First Amendment issue and [is] an attempt by a self-righteous few to sneak their repressive views onto the law books." For McCaffery and others who opposed the legislation, the "fascination with 'satanic messages' is an immediate indication [that] this is another one of the Fundamentalist Christian Rights [sic] perennial attempts to ban rock-n-roll, the music of hell." 29

Many people, however, expressed their support for AB 3741. In newspaper editorials and letters sent to the committee, many people agreed that backmasking and subliminal messages were an invasion of an individual's right to privacy. In another letter to Chairwoman Tanner, Judy Waits of Lancaster, California, expressed her belief that "backward masking and subliminal advertising are an infringement of our basic right of choice. We should be able to choose what we see and what we hear. After all," Waits continued, "we are a product of our native talent and what we have been exposed to either for good or for bad. To deliberately plant a hidden message, either in backward masking in music or subliminal advertising, is to force a private opinion about religion or sex, or marketing, upon the general public. A continual bombardment of our senses without our consent, can lead to a slow eroding of our moral principles." 30 Similarly, Eylene Csaszar of Panorama City, California, considered subliminal messages as "nothing more than a subtle form of BRAINWASHING!!!"31

For many people, AB 3741-if passed-would provide protection for those most susceptible to the lures of backward masking and subliminal messages: children. "Greedy adults," Helen Puttard wrote to Chairwoman Tanner, "seem to have put money-making high above the welfare of our precious children and America's future." 32 "Let us hope and pray," wrote Marion Roth of Phoenix, Arizona, "that our children who listen 
to these horrible satanic records will realize their little souls are being destroyed by this trash." 33 Dixie Lea Holland succinctly summarized the opinions of many supporters of AB 3741: "I am for this Assembly Bill. Please cast my vote against Satan." 34

Although the bill did not move past the hearing, supporters of AB 3741 scored a series of minor victories in their attempt to include warning labels on records containing backward messages. Soon after the hearing on $\mathrm{AB}$ 3741, people across the country were introduced to the subjects of backward masking and subliminal messages in rock records. The UPI and AP news agencies carried many reports, and a segment on Wyman's bill was also featured on the CBS Evening News. Almost immediately, Chairwoman Tanner and other committee members received inquiries from elected officials in other states (including Ohio and Texas) requesting materials relating to AB 3741. Later in 1982 a bill was introduced in Arkansas-SB 336 - that also called for warning labels on records that purportedly contained backmasked or subliminal messages. In February 1983 SB 336 passed in both the House and Senate before being returned by Governor Bill Clinton to the Senate, where it was subsequently defeated.

A similar bill was also introduced at the federal level. In May 1982 Robert Dornan, a member of the House of Representatives from California, introduced HR 6363, the so-called Phonograph Record Backward Masking Labeling Act of 1982. Dornan's bill called for a label on all records that contained backward masking that read: "WARNING: THIS RECORD CONTAINS BACKWARD MASKING THAT MAKES A VERBAL STATEMENT WHICH IS AUDIBLE WHEN THIS RECORD IS PLAYED BACKWARD AND WHICH MAY BE PERCEPTIBLE AT A SUBLIMINAL LEVEL WHEN THIS RECORD IS PLAYED FORWARD." Record companies that failed to include a warning on records that contained backmasked messages would be guilty of an "unfair and deceptive act" as described in section 5 of the Federal Trade Commission Act. Dornan's proposed bill never made it past the House of Representatives.

Between 1982 to 1983 attempts on the part of lawmakers to pass legislation requiring warning labels on records that allegedly contained backmasked messages failed for a variety of reasons. First, there was no agreement that the examples of backward lyrics generally submitted as evidence-Led Zeppelin's "Stairway to Heaven," Styx's "Snowblind," and Electric Light Orchestra's "Fire Is High," for example-were intentionally placed on records by the artists or the record companies. ${ }^{35}$ Second, if the lyrics were present, there was often no agreement on what the lyrics actually were. A member of the Committee on Consumer Protection and Toxic Materials admitted to Billboard magazine that she was unable to decipher the backward messages without the assistance of a lyric sheet conveniently provided by William Yarroll. ${ }^{36}$ Third, if backward 
messages were present on phonograph recordings, there was no evidence to support the claims that these messages can be interpreted or decoded by the mind and, therefore, that they can affect behavior. ${ }^{37}$ Fourth, if the lyrics were present and their meanings could be firmly established, and if these lyrics could somehow be shown to influence complex behavior, legislators would then have to consider these messages in the context of protected speech. Given these reasons, it is easy to see why the bills in California and Arkansas and in the United States House of Representatives all failed.

While politicians were unable to convince fellow legislators about the insidious effects of backward messages on rock recordings, a number of religious leaders (both ordained and self-proclaimed) were eager to spread the word about the corrupting influence of rock recordings on America's youth. For many evangelists, preachers, and ministers, the latest revelations about rock records containing backward messages glorifying Satan became the topic of sermons, seminars, and books. Beginning with Jacob Aranza's Backward Masking Unmasked in 1983, subliminal messages became a selling point for Christian authors of books and pamphlets that were critical of rock and roll. Dan and Steve Peters (the Peters Brothers) were undoubtedly the most active opponents of rock and roll. Between 1984 and 1985, the Peters Brothers published three books-The Peters Brothers Hit Rock's Bottom! (1984), Why Knock Rock? (1984), and Rock's Hidden Persuader: The Truth About Backmasking (1985)and appeared on numerous radio and television news programs, including the CBS Evening News and ABC's Nightline. They hosted seminars in churches, community centers, and schools across the country where they preached about the supposed evils of rock and roll as they sold their informational books, tapes, and videocassettes. ${ }^{38}$

The Peters Brothers, Aranza, and other antirock authors exploited the growing concerns in America regarding backmasking and subliminal messages. In their books, these authors would briefly describe the technology employed in backmasking and then cite many of the same musical and lyrical examples first presented by Yarroll as part of the hearings on AB 3741 in 1982. After the authors emphasized the supposed satanic and occult aspects of subliminal messages, most of these antirock publications would then be organized as a series of chapters on other "immoral" aspects of the rock-and-roll lifestyle, including drug and alcohol abuse, casual sex, homosexuality, explicit album covers and artwork, fashion and appearance, live performances, celebrations of non-Christian religions and spiritual beliefs, and lyrics (including lyrics that are heard when records are played in their intended direction). ${ }^{39}$ Unlike politicians and legislators, authors of antirock books did not question the presence of subliminal messages on rock recordings nor their ability to influence behavior. Furthermore, given the fact that the intended audience for 
their books typically included people with deep religious convictions, authors such as Aranza and the Peters Brothers could respond to skeptics by appealing to scripture. As Aranza recounts in Backward Masking Unmasked, "After I finished doing a radio program on backward masking one evening, a man called me and was very angry. He had heard what I said about backward masking and was insulted by what I'd said about his favorite group. And even though he heard these backward messages he didn't believe it. That's exactly what Satan wants us to believe. Because as long as we'll ignore [Satan] and the tools that he is using he can continue to proclaim his message. The scriptures say, 'My people are destroyed for lack of knowledge.'"'40

The Peters Brothers' Why Knock Rock? introduced readers to a new danger associated with rock music: teen suicide. In a chapter entitled "Don't Fear the Reaper" (a reference to the popular song by the band Blue Öyster Cult), the authors describe how rock music "has often been the deciding factor that pushes someone over the brink to choose suicide." In support of their claim, the authors describe the musical preferences of American teenagers who had recently committed or attempted suicide. According to the authors, songs by bands such as Pink Floyd, AC/DC, Black Sabbath, Ozzy Osbourne, John Lennon, and Grand Funk Railroad "destroy[ed] the minds of young people and shov[ed] them to the brink of despair and ultimate disaster." In an effort to protect susceptible minds from "the deathly influence of rock music," the Peters Brothers urged parents and teenagers to review lyrics, album covers, and lifestyles of artists and bands. If you discover anything that "pollutes your body or affects your mind, get rid of it!" they urged..$^{41}$ The Peters Brothers conclude their chapter with suggestions for troubled teens and concerned parents. In addition to turning to scripture, the Peters Brothers also suggest buying copies of their books and tapes or attending their "Truth About Rock" seminars.

The tragic accounts of teenagers committing or attempting suicide presented in Why Knock Rock? are drawn from articles appearing in the religious periodicals Shofar and Cornerstone. ${ }^{42}$ Originally published in Shofar, Jerry Solomon's "Between Rock and a Hard Place" is a standard antirock text that calls for greater "discernment" on the part of parents concerned about the musical and lyrical messages of contemporary rock music. Like many other antirock critics writing against the backdrop of religion, Solomon adopts a standard Platonic view of the power of music to modify and influence behavior. "Rebellion," Solomon writes, "which is often on the minds of young people, finds its way into many songs. Violence is not far behind. A sensitive chord is strummed when someone hears a song that aligns with his feelings of frustration and anger." Elsewhere, Solomon offers an aside, recounting his conversation with a woman whose nephew, she claimed, killed himself while listening to 
John Lennon's song "Cold Turkey." Solomon is quick to point out that Lennon's song "didn't necessarily make him take his life, but surely it added to his severe despair." ${ }^{33}$ The account in Cornerstone entitled "Teenage Wasteland" (a reference to the Who's song "Baba O'Riley") attributes increased rates of suicide to a variety of "pressures of the 80s," including divorce and the erosion of support systems offered by the traditional "nuclear family," increased pressures to succeed in sports and academics, and the steady stream of reports of "assassinations, world hunger, rape, murder, unemployment, and the threat of nuclear war." ${ }^{\prime 4}$ Nowhere in the article, however, is music mentioned as a contributing factor in teen suicide.

In an effort to sensationalize their views on the corrupting influence of rock and roll, it is clear that the Peters Brothers added references to popular music to previously published (possibly anecdotal) accounts of teen suicide. Even if their accounts of teenagers committing suicide while listening to music could not be verified, the Peters Brothers and other antirock activists were cautious. In their accounts of teen suicide, popular music was never identified as a cause but was instead considered a "contributing factor," something that pushed troubled, susceptible teenagers "over the edge." As national fears concerning the "Satanic Panic" gained momentum, stories that connected music, teen suicide, violent crime, and the occult began to appear with much greater frequency in American newspapers and on television. ${ }^{45}$

Between 1982 and 1983 AB 3741 and similar pieces of legislation devoted to subliminal lyrics and backmasked messages were presented to the public and the media as a "consumer protection issue" relating to an individual's right to privacy. In the writings and seminars of Christian antirock activists, the claim that subliminal and backmasked messages on rock records can "infiltrate" a person's subconscious mind and modify behavior was expanded. In this expanded view, the subconscious mind and the conscious mind were under attack by lyrics (including backmasked messages), album covers and artwork, music videos, and live shows. All of these aspects of contemporary rock and popular music, it was argued, threatened the physical and mental well-being of listeners, especially children and teenagers. For Christian antirock writers and activists, repeated exposure to objectionable content or explicit lyrics encouraged listeners to engage in "risky" forms of behavior commonly associated with teenagers and adolescents, including casual sex and the use of drugs and alcohol. At the same time, these critics argued, rock music's ability to modify behavior and beliefs could also result in violence and, in some instances, lead to suicide. By expanding the range of what was considered "objectionable" and how such content could influence behavior, antirock activists developed a method of critiquing rock and popular music that did not necessarily involve an appeal 
to religion or specific religious beliefs. Beginning in 1985, this newly developed critique was employed by concerned parents and political lobbying groups who appealed to notions such as "moral standards" and "family values" in an effort to protect America's children from the dangers posed by much contemporary popular music.

\section{The PMRC, "Porn Rock," and Parental Advisories}

On May 6, 1985, Newsweek published an opinion piece by the journalist Kandy Stroud entitled "Stop Pornographic Rock." In her piece, Stroud acknowledges that suggestive lyrics and sexual innuendo have always been associated with rock and roll. "But as both a parent and musician," Stroud explains, "I am concerned about the number of hit tunes that can only be called porn rock, and about the tasteless, graphic and gratuitous sexuality saturating the airwaves and filtering into our homes." "Whether it's satanic, sexual or drug-oriented," Stroud explains, ". . . vulgar lyrics supported by uncomfortably provocative sound effects result in musical pornography." Stroud's opinion piece is a plea to record companies and musicians, urging them to "clean up their acts" and to help "ensure that America's own youth will be fed a diet of rock music that is not only good to dance to but healthy for their hearts and minds and souls as well." 46

Stroud's "Stop Pornographic Rock" was not just the opinion of one parent frustrated by explicit lyrics, graphic album covers, and explicit videos used to promote some forms of contemporary popular music. Appearing in a magazine read by millions of Americans, "Stop Pornographic Rock" was part of a larger campaign initiated by the recently formed nonprofit organization the Parents' Music Resource Center (PMRC), led by Tipper Gore and Susan Baker. ${ }^{47}$ Capitalizing upon the media attention generated by Stroud's opinion piece, members of the PMRC made their first public appearance on May 15 (the day before "The Devil Worshippers" aired) in Washington, DC, where they hosted an open meeting to discuss the dangers of "porn rock."

Like their antirock contemporaries who linked rock and popular music with Satanism, members of the PMRC were concerned about the mental health and moral well-being of children and teenagers who were repeatedly exposed to sexually explicit, violent, and occult-based lyrics and images in rock music and videos. ${ }^{48}$ In a letter sent to the Recording Industry Association of America (RIAA) in May 1985, the PMRC explained: "It is our concern that some of the music which the recording industry sells today increasingly portrays explicit sex and violence, and glorifies the use of drugs and alcohol. It is indiscriminately available to persons of any age through record stores and the media. These messages reach young children and early teenagers at a crucial age when they are developing 
lifelong value systems. Their minds are often not yet discerning enough to reject the destructive influences and anti-social behavior engendered by what they hear and see in these products." ${ }^{49}$

Christian antirock activists such as Aranza and the Peters Brothers were often content with simply identifying immoral and offensive aspects of song lyrics, album covers, and music videos. To avoid the inherent dangers posed by much popular music, they and other antirock activists often suggested seeking out other forms of music, turning to scripture for strength and advice, and trying to convert rock stars to Christianity. ${ }^{50}$ The PMRC, however, sought a more reasoned, rational, and politically savvy solution to the problem of "porn rock": "Because of the excesses that exist in the music industry today, we petition the industry to exercise voluntary self-restraint perhaps by developing guidelines and/or rating systems, such as that of the movie industry, for use by parents in order to protect our younger children from such mature themes." 51

Of course, the rating system for music suggested by the PMRC was not new. Three years earlier, Assemblyman Wyman's proposed legislation in California (AB 3741) and Representative Dornan's bill before the United States House of Representatives (HR 6363) both sought the inclusion of warning labels on records containing backmasked messages. While Wyman's and Dornan's bills proceeded from the premise that satanic messages were secretly being administered into the minds of unsuspecting children, the PMRC was concerned about objectionable material that could be immediately seen and heard. To illustrate their proposed rating system, the PMRC released a list of fifteen songs they considered to be examples of "porn rock" and the warning labels that could be affixed to album covers. Dubbed the "Filthy Fifteen," the list included songs by Prince, Madonna, and Cyndi Lauper (receiving a label of " $X$ " for "Profane or Sexually Explicit" content); Black Sabbath and Def Leppard ("D/A" for references to drug and alcohol use); Twisted Sister and Mötley Crüe (" $\mathrm{V}$ " for violent content); and Mercyful Fate and Venom ("O $\mathrm{O}$ " for occult references). ${ }^{52}$

Throughout the summer of 1985 the PMRC and members of the RIAA were unable to reach an agreement on what, exactly, constitutes "explicit" content and how a rating system might be implemented. Frustrated that they were unable to make any headway with the music industry, the PMRC took advantage of their political connections and arranged a congressional hearing on the topic of explicit content in rock music and a proposed labeling system. Given the tremendous amount of media attention devoted to the PMRC and the fact that artists such as Frank Zappa, John Denver, and Dee Snider (lead singer of the rock band Twisted Sister) agreed to testify, the hearing scheduled for September 1985 was, in the words of Tipper Gore, "the hottest ticket in town all year." 
The hearing before the Committee on Commerce, Science, and Transportation did not seek new legislation or government regulations regarding a labeling system for records. Instead, as Chairman John C. Danforth (R-MO) noted in his opening statement, the hearing was designed to "provide a forum for airing the issue [of objectionable content in music], for ventilating the issue, for bringing it out in the public domain. The concern," Danforth continued, "is the public at large should be aware of the existence of this kind of music, and the fact that it is now available to kids, and that kids of all ages are able to buy it." 54

Many of the witnesses appearing before the committee who favored a labeling system repeatedly described how explicit lyrics and images on records have a negative influence on children. In his statement before the committee, musicologist Joe Stuessy explained that the "first thing we know is that music affects behavior. .. . We have known intuitively for centuries, and it has been proven conclusively by scientific studies in recent decades that music does affect behavior." 55

We know that music affects behavior. Anyone who says, "I listen to heavy metal, but it doesn't affect me" is simply wrong. Granted, it affects people to different degrees and in different ways. The healthy, stable, mature personality may, in fact, be minimally affected by heavy metal. But many, especially teenagers and pre-teens, are still shaping their self-identities. They are malleable, beset by internal and external conflicts about authority (especially parents), drugs, sex, theology, education, etc. They are in a process of defining who and what they are. At such a time, heavy metal's influence can be significant. ${ }^{56}$

In his written statement submitted to the committee, Stuessy also describes how subliminals, including backmasked messages and what he called "subaudibles" (barely perceptible lyrics or messages mixed at a low volume), can also infiltrate the subconscious mind. While Stuessy admits that much more research is needed in the area of subliminals, he cites the Peters Brothers' Rock's Hidden Persuader: The Truth About BackMasking in support of his claim. ${ }^{57}$

Throughout the hearing, references to the corrupting influences of Satanism and the occult were presented against the backdrop of an agreed-upon (but never articulated) understanding of what was considered morally and culturally acceptable. ${ }^{58}$ In his testimony and in his written statement, Stuessy made no effort to hide his disdain for heavy metal music. "Today's heavy metal music," he explained, "is categorically different from previous forms of popular music. It contains the element of hatred, a meanness of spirit. Its principal themes are ... extreme violence, extreme rebellion, substance abuse, sexual promiscuity and perversion, and Satanism." ${ }^{59}$ Paul King, a child psychiatrist, described 
how troubled adolescents and teenagers can be influenced by satanic elements in contemporary heavy metal: "The heavy metal groups themselves state that ... they are not into Satan worship. Whether this is true or not is not important. Young people feeling inadequate can have an instant sense of power from the music and identification [sic] closely with the lyrics. Heavy metal portrays the power and glory of evil. Adolescents with emotional and/or drug problems, which I treat every day, become further involved in delinquent behavior, violence, acts of cruelty, and Satan worship." ${ }^{60}$ King recited the opening lyrics to Iron Maiden's song "Number of the Beast" as an example of a heavy metal song that glorifies Satanism. King did not mention, however, that these lyrics are drawn from the book of Revelation (12:12 and 13:18). ${ }^{61}$

Throughout the hearing, explicit lyrics and objectionable content in rock music were linked to a host of societal ills. In a written statement, psychologist and sex therapist Martha Winter Gross identified numerous challenges and hardships facing America's youth:

Teen-age pregnancies are at an all-time high and our children are bombarded daily on the airwaves with free-love proclamations. Children, like many adults, are turning to alcohol and drugs to deal with anxiety and stress. And rock music lyrics encourage-rather than discourage - their use. Abused or neglected youngsters are running away from home in greater numbers, ending up making their living on the streets as prostitutes or criminals. Child pornography is increasing, and where there is child pornography there are child abusers. An alarming number of children are being reported missing - many of them never to be found or found dead at the hands of a molester. ${ }^{62}$

Gross made it clear, however, that she was "not prepared to say that violence and sexual explicitness communicated in some of today's rock music causes antisocial behavior, [but] I certainly think it sets the stage." 63

During the hearing, many committee members and witnesses addressed the correlation between rock lyrics and teen suicide. During his testimony, Jeff Ling, a former rock musician turned Episcopal priest, explained that nearly " 6,000 [teenagers] will take their lives this year. Many of these young people find encouragement from some rock stars who present death as a positive, almost attractive alternative. ${ }^{\prime 64}$ Following Ling's testimony, Chairman Danforth returned to the topic of teen suicide:

Mr. Chatrman: Now, Mr. Ling, you pointed out at the beginning of your presentation that you do know of a couple of cases where kids have committed suicide while listening to rock music that advocates suicide. Do you believe that these are rare cases of rock music influencing behavior, or do you think that it is more 
commonplace? In other words, do you think that this music is tasteless, but that it does not have very much effect, or do you think that the music has some negative consequences?

Mr. LING: I think it has great effect. As one who has worked with teenagers and college students on a professional level for the last 10 years, I have watched the things that they have watched, and listened to what they have listened to. I have seen their behavior influenced and encouraged by this music. More importantly, sir, the problem is that the music might reflect the behavior, attitudes, [and] values of those in the 18 or older bracket. However, when that music is listened to by 12-year-olds, 11-year-olds, and 10-year-olds, it moves from the area of being a reinforcer [ $\mathrm{sic}]$ and an encourager into the role of educator, and many of these young children are being educated in these things before they have any kind of frame of reference to properly put it in. ${ }^{65}$

Throughout the hearings and in written statements submitted to the official record, members of the PMRC and their supporters provided many examples of teenagers who had committed suicide while listening to music. Except for one account, all of the examples were drawn from the Peters Brothers' book Why Knock Rock? ${ }^{66}$

As described in their opening statements before the committee, members of the PMRC repeatedly emphasized that the labeling system they proposed was not an attack on free speech or a form of censorship. Instead, they argued, their request of the music industry to include warning labels on recordings was a commonsense measure designed to assist parents in determining what music was appropriate for their children and that reflected their own personal, family values. "Now that more and more elementary school children are becoming consumers of rock," Susan Baker explained, "we think it is imperative to ask this question: What can be done to help parents who want to protect their children from [harmful messages] if they want to?"67 In her statement, Tipper Gore acknowledged that the "issue [debated during the hearing] is larger than violent and sexually explicit lyrics. It is one of ideal freedoms and responsibility in our society. Clearly, there is a tension here, and in a free society there always will be. We are simply asking that these corporate and artistic rights be exercised with responsibility, with sensitivity, and some measure of self-restraint, especially since young minds are at stake. We are talking about preteenagers and young teenagers having access to this material. That is our point of departure and our concern."68

The hearing proved favorable for the cause of the PMRC and its supporters. On November 1, 1985, the RIAA reached an agreement with the PMRC that a warning label be affixed to recordings containing explicit content. The parties finally revealed the new logo in May 1990: a blackand-white sticker reading "Parental Advisory-Explicit Lyrics." The 
advisory label was voluntary and would be applied at the discretion of record labels and artists.

\section{Subliminals, Suicide, and Free Speech in Court}

The tremendous amount of media coverage devoted to the PMRC hearing fueled existing debates regarding music's ability to affect behavior. Shortly after the hearing concluded in September 1985, many of the speculative claims regarding the dangers of "porn rock" provided by the PMRC were debated in courtrooms throughout the country. In multiple cases involving heavy metal acts, debates concerning subliminal and backmasked messages, the possibility that lyrics can modify behavior, and if/how such messages and lyrics are protected under the First Amendment were argued as part of wrongful death lawsuits filed by families whose children had committed suicide.

On October 25, 1985, a wrongful death lawsuit was filed against heavy metal singer Ozzy Osbourne and CBS, his record company. The lawsuit alleged that the lyrics to Osbourne's song "Suicide Solution" led John McCollum, a teenager from California, to commit suicide the previous year. In the suit, McCollum's parents claimed that Osbourne's song encouraged suicide as a "solution" to life's problems. In his defense, Osbourne stated that the song was about the dangers of alcohol abuse and that the word "solution" referred to liquids. In August 1986 the trial court judge dismissed the case. In July 1988 an appellate court upheld the dismissal, ruling that the lyrics were protected under the First Amendment and that no matter how the word "solution" was interpreted, there was no proof that suicide was a foreseeable consequence. ${ }^{69}$

Ozzy Osbourne and CBS were named as defendants in another wrongful death suit filed in Georgia in April 1988. In this suit, Thomas and Myra Waller claimed that "Suicide Solution" was a proximate cause in the death of their son, Michael, who had committed suicide in May 1986. Unlike the McCollum case, which alleged that the ambiguous message of the lyrics (and, to a lesser extent, the music) contributed to John McCollum's death, the plaintiffs in the Waller lawsuit argued that subliminal messages contained in Osbourne's song contributed to Waller's decision to take his own life. However, after many tests by multiple audio experts who examined the song's original master tapes, the plaintiffs were unable to conclusively identify subliminal messages in "Suicide Solution." Following many amended complaints, the case was finally dismissed in May 1991. In his ruling, District Judge Duross Fitzpatrick explained how:

given every opportunity to find the subliminal message, using tests they stated were the only ways to confirm its existence, plaintiffs 
failed to present any evidence from which a reasonable fact finder could even infer that a subliminal message existed within the song "Suicide Solution." ... Plaintiffs failed to demonstrate the existence of a subliminal message or that defendants' music incites imminent lawless activity, and were thereby left with the difficult task of attempting to impose liability on the defendants based on their dissemination of speech fully protected by the First Amendment. It was a task plaintiffs were unable to accomplish. ${ }^{70}$

In his ruling, however, Judge Fitzpatrick explained that the plaintiffs might have had a viable case if subliminal messages had been discovered on the recording. "The court," Fitzpatrick wrote, ". . is convinced that the presence of a subliminal message, whose surreptitious nature makes it more akin to false and misleading commercial speech and other forms of speech extremely limited in their social value, would relegate the music containing such to a class worthy of little, if any, First Amendment constitutional protection."71 Fitzpatrick's opinion regarding the "surreptitious nature" of subliminal messages and the limited protection such messages were granted under the First Amendment was informed by a ruling handed down in yet another civil lawsuit involving subliminal messages, suicide, and the music of another heavy metal band, Judas Priest.

In December 1985, after a day of drinking and drug use, two teenage boys entered a park in Sparks, Nevada, and shot themselves. One of the boys, Ray Belknap, died at the scene; the other boy, James Vance, survived. Shortly after the tragic events of December 1985, Vance wrote to Belknap's mother explaining that he believed that "alcohol and heavy metal music such as Judas Priest led us to be mesmerized."72 Based on this information, the families of Vance and Belknap filed a civil suit in Reno, Nevada, in 1988, alleging that the suicide pact was the result of messages in songs on the album Stained Class by the British heavy metal band Judas Priest, messages that purportedly promoted and encouraged suicide.

In a pretrial hearing, James Vance referenced lyrics from Judas Priest's song "Beyond the Realms of Death" — notably the lines "Keep the world with all its sin, it's not worth living in" — as being influential in the suicide pact he formed with Belknap. Given the recent dismissal in McCollum v. Osbourne, the lawyers representing the families of Belknap and Vance (who died in 1988) understood that their case might also be dismissed if they argued that Judas Priest's lyrics influenced the boys' decision to kill themselves. ${ }^{73}$ Therefore, the attorneys adopted a strategy that claimed the boys' actions were the result of subliminal messages. According to the suit, the garbled and nearly indecipherable exhortation to "Do it!" appears on the song "Better by You, Better Than Me." Furthermore, the 
subliminal command to "Do it!" the attorneys argued, became lodged in the boys' minds and, in the context of the heard, or superliminal, lyrics (such as "Tell her the world's not much living for"), directly contributed to the decision to take their own lives.

In addition to subliminal messages, the attorneys also claimed that certain songs on Stained Class contain backward messages that infiltrated the minds of Vance and Belknap. According to evidence presented by audio experts, the song "White Heat, Red Hot" contains a backward message that, when heard forward, states, "Fuck the Lord, fuck all of you!" and the album's title track, "Stained Class," includes the message "Sing my evil spirit!" Once decoded by Vance and Belknap, it was argued, the blasphemous and evil messages entered their conscious minds.

The district judge presiding over the case, Jerry Carr Whitehead, agreed with the families' attorneys and ruled that subliminal messages (including backmasking) are not protected under the First Amendment. Judge Whitehead's ruling was based upon his belief that subliminal messages, by their very nature, are used to manipulate the behavior of listeners without their knowledge. Furthermore, Judge Whitehead continued, because people are unable to protect themselves from the manipulative influence of subliminal messages, such messages violate an individual's right to privacy.

After a month-long bench trial, Judge Whitehead ruled in favor of the defendants, Judas Priest and CBS Records. In his decision, Judge Whitehead stated that while subliminal and backmasked messages were present on certain songs, it was not clear that they were inserted intentionally by the band or the record label. The subliminal command to "Do it!" was determined to be the result of a vocal exhalation by lead singer Rob Halford combined with the timbre and articulation of an electric guitar. Furthermore, Judge Whitehead ruled that the plaintiffs failed to prove that subliminal messages affect behavior. "The plaintiffs lost this case," Whitehead explained, "because they failed to prove that the defendants intentionally placed subliminal messages on the album and that those messages were a cause of the suicide and attempted suicide involved in this case." Although he ruled in favor of the defendants, Whitehead declined to dismiss the case, stating that "it is unknown what future information, research and technology will bring to this field [of subliminals]." 74

Although Ozzy Osbourne and the members of Judas Priest (along with their record company) prevailed in their separate civil suits, it would be incorrect to believe that many of the claims and theories made by antirock authors regarding the ability of lyrics-including subliminal and backmasked lyrics - to influence behavior had finally been laid to rest. In many ways, Judge Whitehead's opinions regarding subliminal 
messages provided legal justification and support for many of the dubious theoretical claims and psychological theories advanced by antirock activists beginning in the early 1980s. First, Judge Whitehead assumed that subliminal messages can influence behavior. Although many people readily accept that subliminal messages can affect behavior, there was a substantial amount of evidence available at the time of Judge Whitehead's ruling that suggested otherwise. ${ }^{75}$ Second, backmasked messages not only were considered a form of subliminal speech but also, in Judge Whitehead's opinion, could be decoded by listeners. Almost as soon as claims of backmasked messages began to appear in the media in the early 1980s, the topic was investigated by psychologists and linguists, and in multiple studies, researchers were not able to show that subjects had the ability to decode backmasked messages. Furthermore, if the backmasked messages couldn't be decoded, there was little chance that these messages could affect behavior. ${ }^{76}$ Finally, Judge Whitehead's view of subliminal messages assumed that the meaning of such messages is fixed by the sender and is understood by the unsuspecting listener. According to this view, it is impossible to misunderstand, misinterpret, or reinterpret subliminal messages; they are semantically fixed commands. Because of this view, Judge Whitehead ruled that subliminal messages-if it can be proven that they were intentionally placed in an advertisement, film, or piece of music - are not protected under the First Amendment.

Three days after Whitehead's decision, Timothy Post, an attorney who represented the mother of James Vance in the recently concluded trial, published an opinion piece in the Los Angeles Times. Entitled "Mind Intrusion Is the Worst Kind of Invasion of Privacy," Post sought to clarify that the trial was not about censorship or First Amendment rights. "Instead," Post explained, "this lawsuit was a product liability case wherein a defective product was placed in the stream of commerce causing harm." Post was pleased with Judge Whitehead's decision to not dismiss the case. "Although the judge found in favor of the defendants," Post wrote, "he upheld our contention that the subliminal messages were in the record [Judas Priest's Stained Class] and that subliminal stimuli can cause behavioral changes." In light of the recent ruling, Post offered a warning to record companies: "Those in the music industry who might be employing subliminals should stop the practice immediately. Of course, they would then have to rely on talent alone to sell their albums. If the outcome of this case allows entertainers to believe that the technology of detection will never catch up with the technology of deception, then they might continue to dabble with subliminals as a marketing ploy. ... If artists who use subliminals don't develop more self-restraint and a concern for their consuming public, then a resentful public will turn on them." 77 


\section{Conclusion: Satanic Fatigue and a New Musical Menace for the 1990s}

At the dawn of the 1990s, record company executives and the American public-despite Post's warning-were not particularly concerned about the supposed dangers posed by subliminal and backmasked messages. By the end of the previous decade, the various religious, political, and cultural movements that enabled early fears regarding subliminal and backmasked messages to take root and flourish had run their course.

Although neoconservative religious ideals and principles continued to exert a strong influence on American politics and culture in the 1990s (and beyond), many of the leaders and organizations originally associated with the New Christian Right saw their power and influence diminish as the 1980 s drew to a close. ${ }^{78}$ Many scandals involving high-profile evangelical leaders tarnished the "family values" image of the movement in the minds of many Americans. In 1988 Jimmy Swaggart, a popular televangelist and a strong supporter of the New Christian Right, was discovered in the company of a prostitute. In 1987 reports surfaced that Jim Bakker, another powerful and influential televangelist, paid money to cover up the sexual assault of his former assistant Jessica Hahn. In 1989 Bakker was also convicted of fraud after it was revealed that he had embezzled more than $\$ 150$ million from his organization, the Praise the Lord Ministries.

In addition to these and other scandals, the New Christian Right as an organized movement began to unravel. In November 1987 Jerry Falwell, the public face and de facto leader of the New Christian Right, announced that he was resigning from his position as president of Moral Majority, Inc. Falwell's decision was the result of many factors, including a steep decrease in contributions to Moral Majority, Inc., and growing disputes with other New Christian Right leaders and organizations regarding the future of the movement. While evangelical voters and New Christian Right organizations were united in their support of Ronald Reagan during his terms as president, they were not united behind a single candidate for the 1988 elections. Leading up to the 1988 elections, support by moderate evangelicals was split between three candidates (Bob Dole, Jack Kemp, and George H. W. Bush), while fundamentalists supported Pat Robertson, a televangelist who claimed to be a faith healer who could speak in tongues. The inability to unite behind a single candidate revealed a sharp rift within the movement. On one side were those who understood the importance of supporting a Republican candidate sympathetic to the ideals and goals of the New Christian Right, and on the other side were those who preferred a charismatic religious leader.

As the 1980s drew to a close, America's fears concerning Satanism had also begun to wane. In October 1988 journalist Geraldo Rivera 
hosted Devil Worship: Exposing Satan's Underground, a two-hour special on NBC. Rivera's special aired during prime time, and although it was presented as a special investigative news report, Exposing Satan's Underground was produced through NBC's entertainment division. ${ }^{79}$ While Exposing Satan's Underground was viewed by nearly twenty million Americans, the show's tabloid style of presentation and its reliance on graphic images and descriptions, unverified stories, and wild conjectures proved to be an embarrassment for NBC. ${ }^{80}$ The Washington Post considered it the worst television program of 1988, explaining that "Geraldo Rivera elicits sympathy for the Devil, but none for himself. . . Proof there really is a hell." ${ }^{81}$ In a scathing review also published in the Washington Post, Tom Shales wrote that the American public "can stop worrying about the breakdown of standards in broadcasting because there are almost no standards left to break down." Shales continued: "'Devil Worship: Exposing Satan's Underground' plumbed uncharted depths in dirty-minded teleporn." 82

The broadcast of Exposing Satan's Underground in October 1988 marked a turning point in the "Satanic Panic" that had captivated the country since the early 1980s. After years of sensationalized and unverified claims regarding the extent and influence of occult activity throughout the country, the American public appeared to be suffering from "satanic fatigue." Regarding the oft-repeated claims connecting music to Satanism, pornography, and violence, many critics had grown tired of the antirock rhetoric and heavy-handed morality of Christian antirock activists. ${ }^{83}$ Furthermore, in their continuing war against objectionable content in music, the PMRC, conservative political leaders and pundits, and fundamentalist conservative organizations such as the Focus on the Family and the American Family Association had identified a new musical threat in the 1990s: rap.

The discursive and rhetorical strategies used to denounce rap, however, were markedly different from those typically employed in earlier debates concerning "porn rock" and heavy metal. Sociologist Amy Binder has compared the various discursive and interpretive frameworks commonly employed in discussions relating to the dangers of heavy metal and rap that appeared in various publications during the 1980s and early 1990s. Binder notes how, in discussions of rap, "[mainstream] writers were no longer concerned about the detrimental effects of the graphic music on teenaged listeners as they had been for heavy metal, but were concerned about the dangers . . . black youths posed to the society at large." ${ }^{84}$ Historian and cultural critic Tricia Rose also recognizes the different media portrayals for rap and heavy metal, noting how, "unlike heavy metal's victims, rap fans are the youngest representatives of a black presence whose cultural difference is perceived as an internal threat to America's cultural development." 85 
In addition to portrayals of rap as a threat to society, early critics would often invoke stereotypical socioeconomic and cultural factors in an attempt to explain why rappers used such explicit and violent language. In her "Hate, Rape and Rap" from 1990, for example, Tipper Gore decries depictions of violence, misogyny, and the use of racial epithets in contemporary rap music and videos, specifically in the songs of rapper Ice-T. ${ }^{86}$ Furthermore, Gore attributes the widespread usage of violent, degrading, and demeaning lyrics in rap to the possibility that there are "few positive black role models for young children [in the black community], and [that] such messages from existing role models are damaging." Gore suggests that rap lyrics are autobiographical and are a reflection of the language, lifestyle, and experiences of a particular socioeconomic segment of the American population (i.e., black, poor, uneducated, and violent). More disturbing for Gore, however, is the "perpetuation-almost glorification — of the cruel and violent reality of [the] 'streets'" in contemporary rap. To those who might argue that rap is harmless or that rappers are just trying to make money by provoking and shocking people, Gore responds that "[cultural] economics were a poor excuse for the South's continuation of slavery. Ice- $T$ 's financial success cannot excuse the vileness of his message. ... Hitler's antisemitism sold in Nazi Germany. That didn't make it right." Gore acknowledges that gang activity, drugs, prostitution, violence, and other forms of criminal activity are prevalent in economically depressed black communities. However, the violent reality of "the streets" of black America is not a reality she thinks her children-and the children of other "respectable" Americans-need to know about.

In the late 1980s and early 1990s, the newly developed discursive frameworks that warned of the dangers of rap were employed by critics, politicians, and law enforcement officials. Following the release of their song "Fuck the Police" in 1989, for example, the rap group N.W.A. was subjected to harassment and obstruction by local law enforcement officials and the FBI. ${ }^{87}$ In June 1990 a US district court judge ruled that the 1989 album As Nasty as They Want to Be by the rap group 2 Live Crew was obscene and therefore could not be sold in certain counties in Florida. ${ }^{88} \mathrm{~A}$ few days after the ruling, a record store retailer was arrested for selling a copy of the album to an undercover police officer, and on June 9, 1990, members of 2 Live Crew were arrested in Florida after performing live. In 1992 the song "Cop Killer" by the heavy metal band Body Count (led by Ice-T) was indirectly linked to the murder of police officers, as well as to the riots that occurred in Los Angeles following the acquittal of police officers in the beating of motorist Rodney King. President George H. W. Bush, Vice President Dan Quayle, and police organizations throughout the country publicly denounced "Cop Killer" and urged Warner Records Group and its parent company, Time Warner 
Cable, to cease distribution of the song. In an effort to shame Time Warner Cable, actor and Time Warner Cable shareholder Charlton Heston, speaking in a voice that brought to mind his role as Moses in the film The Ten Commandments, recited lyrics from "Cop Killer" at the group's annual stockholder meeting in July $1992 .{ }^{89}$

Throughout the 1980s, antirock authors and activists identified numerous examples of musical lyrics, album artwork, and videos that in their opinion had the ability to modify behavior. Critics and defenders of rock and popular music appeared in courtrooms throughout the country and before a congressional committee, where they were allowed to argue how explicit lyrics and objectionable content might have a negative influence on American children and teenagers. By the end of the 1980s and into the 1990s, rap music, by contrast, posed an immediate and very real threat to American society. For rap's critics, it wasn't a question of might but when and how the music, its performers, and its fans would contribute to the decay of American society.

\section{NOTES}

I wish to thank Jessica Herrick at the California State Archives for her assistance in locating materials relating to Assembly Bill 3741 and Brent Singleton at California State University, San Bernardino, for providing me with newspaper articles. I would also like to thank Travis Stimeling, Seth Coluzzi, and the anonymous reviewers at American Music for their comments and suggestions.

1. "The Devil Worshippers," 20/20, ABC, May 16, 1985, https://www.youtube.com/ watch?v=_UQuwxBgpAg (accessed November 24, 2017).

2. See Linda Martin and Kerry Segrave, Anti-Rock: The Opposition to Rock ' $n$ ' Roll (Hamden, CT: Archon Books, 1988), 281-90; R. Serge Denisoff, Tarnished Gold: The Record Industry Revisited (New Brunswick, NJ: Transaction Books, 1986), esp. 377 ff.; and Roy Shuker, Understanding Popular Music, 3rd ed. (New York: Routledge, 2008), 232-33. See also Lawrence Grossberg, We Gotta Get Out of This Place: Popular Conservatism and Postmodern Culture (New York: Routledge, 1992).

3. By the middle of the 1980s, fears regarding Satanism were so widespread in America that in September 1985 Senator Jesse Helms (R-NC) proposed an amendment to an appropriations bill requesting that no federal funds be granted to "any cult, organization, or other group that has a purpose, or that has any interest in, the promoting of satanism or witchcraft." In an effort to sway his fellow senators to adopt the amendment, Helms played the entire episode of "The Devil Worshippers." See Senator Helms speaking on HR 3036, 99th Cong., 1st sess., Congressional Record 131 (September 26, 1985): S 25077-25080.

4. See James T. Richardson, Joel Best, and David G. Bromley, eds., The Satanism Scare (New York: Aldine de Gruyter, 1991); and Jeffrey S. Victor, Satanic Panic: The Creation of a Contemporary Legend (Chicago: Open Court, 1993).

5. Religious scholar Martin E. Marty is often credited as the first to use the label "New Religious Right" to describe these various religious-political organizations. See Marty, "Morality, Ethics, \& the New Christian Right," Hastings Center Report 11, no. 4 (August 1981): 14-17. For a contemporary critique and overview of the New Christian Right, see Robert C. Liebman and Robert Wuthnow, eds., The New Christian Right: Mobilization and Legitimation (New York: Aldine Publishing Company, 1983); and Steve Bruce, The Rise 
and Fall of the New Christian Right: Conservative Protestant Politics in America 1978-1988 (Oxford: Clarendon Press, 1988). See also Daniel Williams, God's Own Party: The Making of the Christian Right (New York: Oxford University Press, 2010); William C. Martin, With God on Our Side: The Rise of the Religious Right (New York: Broadway Books, 1996); and Michael Lienesch, Redeeming America: Piety and Politics in the New Christian Right (Chapel Hill: University of North Carolina Press, 1993).

6. Despite their claims that they were an interdenominational movement, Moral Majority, Inc., and other groups associated with the New Christian Right were comprised almost exclusively of Protestant fundamentalists.

7. See Jerome L. Himmelstein, "The New Right," in Liebman and Wuthnow, The New Christian Right, 13-30. Himmelstein identifies these core ideological beliefs, respectively, as "Economic Libertarianism," "Social Traditionalism," and "Militant Communism."

8. Ibid., 17.

9. See, for example, Tim Lahaye, The Battle for the Mind (Old Tappan, NJ: Fleming H. Revell Company, 1980); and Jerry Falwell, "Future-Word: An Agenda for the Eighties," in The Fundamentalist Phenomenon: The Resurgence of Conservative Christianity, ed. Jerry Falwell with Ed Dobson and Ed Hindson (Garden City, NJ: Doubleday \& Company, Inc., 1981), 186-223. See also David Snowball, Continuity and Change in the Rhetoric of the Moral Majority (New York: Praeger, 1991).

10. Gabriel Fackre, The Religious Right and Christian Faith (Grand Rapids, MI: William B. Erdman's Publishing Company, 1982), 90.

11. David G. Bromley, "Satanism: The New Cult Scare," in Richardson, Best, and Bromley, The Satanism Scare, 49-72; Victor, Satanic Panic, 8-10.

12. On the use of music in Peoples Temple, see my "Music as an Expression of Freedom in the Political Theology of Jim Jones and Peoples Temple," Jonestown Report 14 (October 2014), https://jonestown.sdsu.edu/?page_id=34234 (accessed July 15, 2018).

13. Debbie Nathan, "Satanism and Child Molestation: Constructing the Ritual Abuse Scare," in Richardson, Best, and Bromley, The Satanism Scare, 75-94, 76.

14. James T. Richardson, Joel Best, and David G. Bromley, "Satanism as a Social Problem," in Richardson, Best, and Bromley, The Satanism Scare, 10; Victor, Satanic Panic, 103-25.

15. Harry F. Waters, George Hackett, Jeff B. Copeland, and Jerry Buckley, "The New Right's TV Hit List," Newsweek, June 15, 1981, 101-3.

16. On Wildmon's extended campaign against network television and his relation to the New Christian Right, see Robert R. Mendenhall, "Responses to Television from the New Christian Right: The Donald Wildmon Organizations' Fight against Sexual Content," in Sex, Religion, Media, ed. Dane S. Claussen (Lanham, MD: Rowman \& Littlefield Publishers, Inc., 2002), 101-14.

17. Glen C. Griffin, “Children and Their Music, They're Being Rocked by Audio Pornography," Moral Majority Report, April 20, 1981,15. Griffin's description of contemporary rock and popular music as "audio pornography" would have been understood in relation to another object of scorn for the Moral Majority and other groups associated with the New Christian Right. In his "Agenda for the Eighties," Jerry Falwell explained that the Moral Majority does not "advocate censorship, [but] we do believe that education and legislation can help stem the tide of pornography and obscenity that is poisoning the American spirit today. ... We are not willing to sit back ... while many television programs create cesspools of obscenity and vulgarity in our nation's living rooms" ("Future-Word," 189-90). In the mid-1980s Griffin's deliberately provocative description of some music as "audio pornography" was reformulated as "porn rock." See the discussion of the Parents' Music Resource Center below.

18. Griffin, "Children and Their Music," 15.

19. Martin and Segrave, Anti-Rock, esp. 15-68; and Arnold Shaw, The Rockin' 50s: The Decade That Transformed the Pop Music Scene (New York: Hawthorne Books, 1974). 
20. "Lawmakers Study Measure to Combat Satanic Messages," San Bernardino County Sun, April 29, 1982, B-14.

21. Jay J. de Furia, AB 3741 Bill Summary, April 23, 1982, 1, AB 3741 (1982), California State Archives, Office of the Secretary of State, Sacramento (hereafter AB 3741).

22. Assemblyman Phil Wyman, opening statement, April 27, 1982, AB 3741. On the origins and history of the notion of subliminal influence, see Charles R. Acland, Swift Viewing: The Popular Life of Subliminal Influence (Durham, NC: Duke University Press, 2011). Wyman's appeal to subliminals was probably influenced by the recent-and enormously popular-books of Wilson Bryan Key, including Subliminal Seduction (New York: New American Library, 1974); Media Sexploitation (Englewood Cliffs, NJ: Prentice-Hall, 1978); and The Clam-Plate Orgy (Englewood Cliffs, NJ: Prentice-Hall, 1980). In 1990 Wilson Bryan Key was called as an expert witness for the plaintiffs in the civil lawsuit filed against the heavy metal band Judas Priest (see below).

23. For an overview of the many arguments against the ability of subliminal messages to influence behavior, see Anthony Pratkanis and Elliot Aronson, Age of Propaganda: The Everyday Use and Abuse of Persuasion (New York: W. H. Freeman \& Co., 1992), esp. 199-206.

24. When pressed about his academic and medical credentials, Yarroll admitted that he did not hold any college degrees and described himself as a "self-taught" neuroscientist. Sources at the University of Colorado could not verify that Yarroll had ever conducted research at the Health Science Center. Joe Quintana, "The Devil and Rock 'n' Roll: Sacramento Faces the Music," Los Angeles Herald Examiner, April 28, 1982, A-1, B-9. Yarroll was the featured guest on the Praise the Lord episode that prompted Monika Wilfley to contact Assemblyman Wyman about backmasked messages on rock records.

25. William H. Yarroll II, “Rock Music: Does It Have a Secret Message?," n.d., AB 3741.

26. Jennifer Kerr, "Lawmakers Weigh Subliminal Messages in Rock Recordings," Oakland Tribune, April 28, 1982, E-1.

27. Yarroll, "Rock Music," emphasis in original.

28. See the discussion of Yarroll's theory that appears in Jacob Aranza's Backward Masking Unmasked (Shreveport: Huntington House, Inc., 1983), 2. Without Yarroll's verbal explanation during his testimony, journalists described the diagram as "incomprehensible." See John Sippel, "'Demonic' Messages Are Focus of Calif. Proposal," Billboard, May 15, 1982, 4.

29. Martin McCaffery to Chairwoman Sally Tanner, April 28, 1982, AB 3741.

30. Judy Waits to Chairwoman Tanner, April 19, 1982, AB 3741.

31. Eylene Csaszar to Chairwoman Tanner, n.d., AB 3741.

32. Helen Puttard to Chairwoman Tanner, April 26, 1982, AB 3741.

33. Marion Roth to Chairwoman Tanner, April 27, 1982, AB 3741.

34. Dixie Lea Holland to Chairwoman Tanner, mailgram, April 26, 1982, AB 3741.

35. Amid the furor over backward messages on rock recordings, many bands enjoyed poking fun at antirock activists and elected officials. In 1983 Styx released their album Kilroy Was Here, which included a warning label that read "By Order of the Musical Morality, This Album Contains Secret Backward Messages." In the same year, Electric Light Orchestra released Secret Messages, an album that features backward recordings on many songs, as well as anagrams and snippets of Morse code on the album jacket.

36. Sippel, "'Demonic' Messages," 4 . See also the results of an experiment conducted by psychologists Stephen B. Thorne and Philip Himelstein as described in their "The Role of Suggestion in the Perception of Satanic Messages in Rock-and-Roll Recordings," Journal of Psychology 116 (1984): 245-48.

37. For many politicians and religious leaders, the mere presence of backward messages on rock recordings implied not only that listeners comprehended the messages but that these messages altered listeners' behaviors and beliefs. Psychologists John R. Vokey and J. Don Read referred to this as the "fallacy that presence implies effectiveness." See their "Subliminal Messages: Between the Devil and the Media," American Psychologist 40, no. 
11 (November 1985): 1231-39. See also Timothy E. Moore, "The Case against Subliminal Manipulation," Psychology and Marketing 5, no. 4 (Winter 1988): 297-316, esp. 305-6.

38. Dan Peters and Steve Peters, The Peters Brothers Hit Rock's Bottom! (St. Paul: Truth About Rock Ministries, 1984); Dan Peters and Steve Peters with Cher Merrill, Why Knock Rock? (Minneapolis: Bethany House Publishers, 1984); and Dan Peters and Steve Peters with Cher Merrill, Rock's Hidden Persuader (Minneapolis: Bethany House Publishers, 1985). The Peters Brothers also produced and distributed informational videocassettes through their Truth About Rock Ministries. For an example, see https://www.youtube.com/ watch?v=RIRZ97wqOZ4 (accessed November 24, 2017). On antirock (and antirap) writings by religious fundamentalists during the 1980s, see Jason C. Bivins, Religion of Fear: The Politics of Horror in Conservative Evangelicalism (New York: Oxford University Press, 2008), 89-128.

39. In this respect, the writings of Aranza, the Peters Brothers, and others were similar in content and organization to books by earlier antirock authors, especially David Noebel and Bob Larson. See, for example, David A. Noebel, Rhythm, Riots, and Revolution: An Analysis of the Communist Use of Music, the Communist Master Music Plan (Tulsa: Christian Crusade Publications, 1966); and Bob Larson, Rock \& Roll: The Devil's Diversion (McCook, NE: B. Larson, 1967).

40. Aranza, Backward Masking Unmasked, 8.

41. Peters and Peters, Why Knock Rock?, 155, 156, 163.

42. The cited articles are Jerry Solomon, "Between Rock and a Hard Place," Shofar, Fall 1983, 6-13; and Chris Ramsey and Diana Pavlac, "Teenage Wasteland: The Suicide Fantasy," Cornerstone 11, no. 62 (1983): 4-7.

43. Solomon, "Between Rock and a Hard Place," 11.

44. Ramsey and Pavlac, "Teenage Wasteland," 5.

45. A keyword search combining the terms "teen suicide," "music," and "occult" in the ProQuest Historical Newspapers database reveals a dramatic rise in the number of newspaper articles and opinion pieces devoted to these topics beginning in late 1984 . On the alleged relationship between hard rock, heavy metal, and teen suicide during the 1980s, see Robin Wright, "'I'd Sell You Suicide': Pop Music and Moral Panic in the Age of Marilyn Manson," Popular Music 19, no. 3 (October 2000): 365-85, esp. 371-74.

46. Kandy Stroud, "My Turn: Stop Pornographic Rock," Newsweek, May 6, 1985, 14.

47. In the media the PMRC was often referred to as the "Washington Wives." Tipper Gore was the wife of Senator Al Gore (D-TN), and Susan Baker was the wife of the secretary of the treasury, James A. Baker III. Other PMRC members included Ethelann Stuckey, wife of former congressman Williamson Stuckey (D-GA), and Sally Nevius, wife of John Nevius, the former chairman of the District of Columbia City Council.

48. Martin and Segrave, Anti-Rock, 291-314; and Claude Chastegner, “The Parents' Music Resource Center: From Information to Censorship," Popular Music 18, no. 2 (May 1999): $179-92$.

49. Quoted in Tipper Gore, Raising PG Kids in an X-Rated Society (Nashville: Abingdon Press, 1987), 29.

50. In his article on "audio pornography" from 1981, Glen C. Griffin recommends "choosing family favorites to put on cassette tapes for the home. Selected music from Broadway and classic shows, like The Sound of Music, are delightful and timeless" "Children and Their Music," 15). In Why Knock Rock? the Peters Brothers include a list of "Rock and Roll's Ten Most Wanted" that includes contact information for, among others, Prince, Ozzy Osbourne, and members of the bands AC/DC, Judas Priest, and KISS. "If you would like to change the future of rock music," the Peters Brothers write, "please pray for the artists on this list on a daily basis. You might also consider writing to them. Tell them about Jesus and let them know you love them and are praying for them - but also that you cannot tolerate their behavior and recorded material. Give them an opportunity to meet the Lord through you!" (Why Knock Rock?, 263).

51. Gore, Raising PG Kids, 29. 
52. The complete list of the artists and songs that comprised the "Filthy Fifteen" appears in Robert Love, "Furor over Rock Lyrics Intensifies; Senate May Hold Hearings in September," Rolling Stone, September 12, 1985, 13-14.

53. Gore, Raising PG Kids, 33.

54. Record Labeling. Hearings Before the Committee on Commerce, Science, and Transportation, United States Senate, Ninety-Ninth Congress, First Session on Contents of Music and the Lyrics of Records (Washington DC: Government Printing Office, 1985), 1. Hereafter referred to as "PMRC Hearings."

55. Ibid., 117.

56. Ibid., 126, emphasis in original. In support of his claim that it is "intuitively" obvious that music affects behavior, Stuessy, in a prepared statement, provided quotations by Plato and Martin Luther. Regarding the "tons of research" on the topic, Stuessy cites A. P. Merriam's book The Anthropology of Music from 1964 and Paul Haack's "Is Big Brother Watching?," an article that can best be described as a paranoid plea to music educators urging them to resist the efforts of those in power who-like Big Brother in George Orwell's 1984-use music as a form of "mind control." See Paul Haack, "Is Big Brother Watching?," Music Educators Journal 68, no. 9 (May 1982): 25-27.

57. PMRC Hearings, 127.

58. During the hearing, members of the PMRC and their supporters avoided invoking specific religious beliefs or affiliations when justifying their concerns regarding explicit content in music and videos.

59. Ibid., 117.

60. Ibid., 129.

61. In her book, Tipper Gore devotes a chapter to heavy metal music and Satanism. See Gore, Raising PG Kids, 117-25.

62. PMRC Hearings, 162.

63. Ibid., 161.

64. Ibid., 13.

65. Ibid., 46.

66. In her chapter "Merchants of Death: Touting Teen Suicide," Gore recounts many of the same examples of teenagers committing suicide while listening to hard rock or heavy metal music. She cites the Peters Brothers book as a source for her information. See Gore, Raising PG Kids, 103-16.

67. PMRC Hearings, 12.

68. Ibid., 13.

69. Scott Alan Hampton, "Anatomy of a Suicide: Media Liability for Audience Acts of Violence," Loyola of Los Angeles Entertainment Law Review 9, no. 1 (1989): 95-116. During the PMRC hearings, Osbourne's song was singled out multiple times as an example of a song that encouraged suicide.

70. Waller v. Osbourne, 763 F. Supp. 1144, 1153-54 (M.D. Ga. 1991), http:/ /www.leagle .com/decision/19911907763FSupp1144_11731/WALLER\%20v.\%20OSBOURNE\# (accessed November 24, 2017).

71. Ibid., 1149.

72. Larry Rohter, "2 Families Sue Heavy-Metal Band as Having Driven Sons to Suicide," New York Times, July 17, 1990, C13. On the Judas Priest trial and the alleged relations between heavy metal and teen suicide, see also Robert Walser, Running with the Devil: Power, Gender, and Madness in Heavy Metal Music (Middletown, CT: Wesleyan University Press, 2014), 145-51; and Deena Weinstein, Heavy Metal: The Music and Its Culture, rev. ed. (New York: Da Capo Press, 2000), 250-57.

73. Much of what follows regarding the legal arguments presented in the civil suit is based upon Pamela Marsden Capps, "Rock on Trial: Subliminal Message Liability," Columbia Business Law Review 27 (1991): 27-50; Juliet Dee, "Subliminal Lyrics in Heavy Metal Music: More Litigation, Anyone?," Communications and the Law 16, no. 3 (1994): 3-24; and Laura W. Brill, “The First Amendment and the Power of Suggestion: Protecting 'Negligent' 
Speakers in Cases of Imitative Harm," Columbia Law Review 94, no. 3 (April 1994): 984-1044. See also Timothy E. Moore, "Scientific Consensus and Expert Testimony: Lessons from the Judas Priest Trial," Skeptical Inquirer 20, no. 6 (November/December 1996): 32-38, 60. Moore was a witness for the defense during the Judas Priest trial.

74. "Rock Group Cleared in Suicide Case," Washington Post, August 25, 1990, C12.

75. E. J. Zanot, D. Pincus, and E. J. Lamp, "Public Perceptions of Subliminal Advertising," Journal of Advertising 12, no. 1 (1983): 39-45; and Anthony R. Pratkanis and Anthony G. Greenwald, "Recent Perspectives on Unconscious Processing: Still No Marketing Applications," Psychology and Marketing 5, no. 4 (Winter 1988): 337-53. Pratkanis was a witness for the defense in the Judas Priest trial.

76. See, for example, Thorne and Himelstein, "The Role of Suggestion"; and Vokey and Read, "Subliminal Messages." See also Michael W. Walker, "Backwards Messages in Commercially Available Recordings," Popular Music and Society 10, no. 1 (1985): 2-13; and Philip M. Merikle, "Subliminal Auditory Messages: An Evaluation," Psychology and Marketing 5, no. 4 (Winter 1988): 355-72.

77. Timothy Post, "Mind Intrusion Is the Worst Kind of Invasion of Privacy," Los Angeles Times, August 27, 1990, F3.

78. See Bruce, The Rise and Fall, 126 ff.; Williams, God's Own Party, 214 ff.; and Martin, With God on Our Side, 258-98.

79. Devil Worship: Exposing Satan's Underground, NBC, October 22, 1988, https://www .youtube.com/watch?v=EcWbuBPNtPw (accessed November 24, 2017).

80. Diane Hathman, "NBC's Tartikoff Takes Heat for Rivera's Satanism Show," Los Angeles Times, January 9, 1989, J1. It is possible that many people who watched Exposing Satan's Underground were not especially interested in the subject matter but were instead hoping Rivera would repeat the same sensationalized, tabloid-influenced form of television journalism he popularized in his 1986 special, The Mystery of Al Capone's Vaults. They were not disappointed.

81. Tom Shales, "TV '88: From Summit to Plummet," Washington Post, December 25, 1988, G1, G4-G6.

82. Tom Shales, "The Devil to Pay," Washington Post, October 27, 1988, B1, B6.

83. Writing for the Los Angeles Times, Randy Lewis referred to a study carried out by Paul King (a child psychiatrist who testified as part of the PMRC hearing in 1985) that connected drug abuse with Satanism and heavy metal music. "Indisputably," Lewis writes, "heavy metal music has been a central focus in the lives of some teen-agers, as has serious drug abuse and, in certain cases, satanic religious practices. But," Lewis continues, "it's equally true that most teen-agers who get in trouble wear blue jeans, drive cars or eat hamburgers. Rock music — even heavy metal—no more causes teen-agers to become devil-worshipping murderers than marching band music causes football games" ("Rock Can't Shake Its Devilish Reputation," Los Angeles Times, October 30, 1988, AL47D, emphasis in original).

84. Amy Binder, "Constructing Racial Rhetoric: Media Depictions of Harm in Heavy Metal and Rap Music," American Sociological Review 58, no. 6 (December 1993): 753-67, 765

85. Tricia Rose, Black Noise: Rap Music and Black Culture in Contemporary America (Hanover: Wesleyan University Press, 1994), 130. See also Rose, The Hip Hop Wars: What We Talk About When We Talk About Hip Hop — and Why It Matters (New York: Basic Books, 2008).

86. Tipper Gore, "Hate, Rape and Rap," Washington Post, January 8, 1990, A15.

87. Dave Marsh and Phyllis Pollock, "Wanted for Attitude," Village Voice, October 10, 1989, 33-37.

88. Bruce Haring, “Crew's 'Nasty' Ruled Obscene in Florida," Billboard, June 16, 1990, $5,98$.

89. Christopher Sieving, “Cop Out? The Media, 'Cop Killer,' and the De-racialization of Black Rage," Journal of Communication Inquiry 22, no. 4 (October 1998): 334-53. 